Egyptian Veterinary Medical Society

of Parasitology Journal

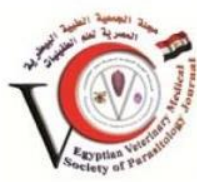

Original Article

\title{
Pharmacokinetics of ceftiofur sodium after intravenous and subcutaneous administration in pre-weaned calves
}

\section{Mohamed El-Hewaity \\ Department of Pharmacology, Faculty of Veterinary Medicine, Menoufia University, Egypt}

Corresponding author:

Dr. Mohamed El-Hewaity

E-mail:melhewaty@yahoo.com

\begin{abstract}
:
The current work was outlined to decide kinetic profile and bioavailability of ceftiofur sodium at measurements of $2.2 \mathrm{mg} / \mathrm{kg}$. b.wt. after a single intravenous and subcutaneous injection in pre-weaned calves. Five clinically typical pre-weaned calves were utilized in this work. Serum ceftiofur concentrations were decided by utilizing high performance liquid chromatography (HPLC) strategy. The serum concentration-time curve has shown a two compartment open model. Taking after a single intravenous injection, distribution half-life ( $\mathrm{t}_{0.5 \mathrm{\alpha}}$ ) was $0.11 \pm 0.01 \mathrm{~h}$, volume of distribution $\left(\mathrm{V}_{\mathrm{dss}}\right)$ was $0.16 \pm 0.004 \mathrm{~L} / \mathrm{kg}$, elimination half-life ( $\mathrm{t}_{0.5 \beta}$ ) was $11.07 \pm 0.12 \mathrm{~h}$ and total body clearance (CLtot) was $0.013 \pm 0.005 \mathrm{~L} / \mathrm{kg} / \mathrm{h}$. Taking after a single subcutaneous organization, ceftiofur had a peak serum concentration $\left(\mathrm{C}_{\max }\right) 6.64 \pm$ $0.08 \mu \mathrm{g} / \mathrm{ml}$ at a time $\left(t_{\max }\right)$ of $3.38 \pm 0.069 \mathrm{~h}$, disposal half-life (to.5el) was $2.11 \pm 0.25 \mathrm{~h}$ demonstrating the propensity of calves to eliminate ceftiofur in slow rate. Bioavailability was $77.04 \pm 1.64 \%$ after subcutaneous injection indicating a good absorption of ceftiofur. Ceftiofur serum concentrations along $36 \mathrm{~h}$ following subcutaneous injection in the current work were exceeding the MICs of different susceptible microorganisms responsible for serious disease problems. These results demonstrating successful use of ceftiofur in pre-weaned calves.
\end{abstract}

Key words: ceftiofur - Pharmacokinetics -HPLC - pre-weaned calves.

\section{INTRODUCTION}

Cephalosporins are a class of beta-lactams antibiotics, they act by halt the blend of the layer of peptidoglycan of bacterial cell wall and inactivate enzymes in the cell wall of sensitive bacteria, avoiding arrangement of cell wall. There are classified into five bactericidal generations (Kapoor et al., 2017; Werth, 2018 \& Moore, 2019). Ceftiofur could be a part of third generation of five generations cephalosporins. It is classified as a broad spectrum which effective against gram-positive and gramnegative bacteria, including $\beta$ lactamase generating strains that refere to additional methoxyimino side chains in the thirdgeneration aminothiazole category of cephalosporin (Baere et al., 2004). Ceftiofur incorporates a bactericidal impact on microorganisms includes Mannheimia haemolytica, Pasteurella multocida, ,Haemophilus somnus, Fusobacterium necrophorum, Arcanobacterium pyogenes, Prevotella melaninogenica, Escherichia coli, Staphylococci and Streptococci (Witte et al., 2011).

The neonatal diarrhea is considered one of the most causes of mortality in young calves 
in veterinary practice, the primary line for treatment is ceftiofur sodium (Altan et al., 2017). Ceftiofur also utilized to treat infections in respiratory system and interdigital dermatitis in meat and milk producer cattles (Salmon et al., 1995). Ceftiofur sodium is endorsed in shipping fever and intense bronchopneumonia after transportation in beef cattle (Stanek and Kofler, 1998), also it used in treatment of acute foot rot in bovine (Kausche and Robb, 2003). Ceftiofur moreover utilized in case held placenta and metritis (Scott et a.,I 2005). Ceftiofur sodium pharmacokinetic profiles show that it is retained rapidly from location of infusion, quickly conveyed through peripheral and central compartments (Brown et al., 1996).

Taking into thought the above facts, this study was performed in order to explore ceftiofur sodium disposition kinetics in preweaned calves following intravenous and subcutaneous injection.

\section{MATERIALS AND METHODS}

\section{Drug:}

Ceftiofur sodium: it could be a sterile powder for parenteral course. It was gotten from Badr Pharma for Pharmaceutical Industries for Pharma Cure Pharmaceutical Industries as sterile powder for injection under trade name (Ceftiprima® one gram).

\section{Animals:}

Five clinically typical pre-weaned calves were utilized in this work. The body weight and age of the tried calves extended from $90-100 \mathrm{~kg}$ and from 6080 days old. They were housed in clean steady, primarily nourished on drain from its dams and eat little sum of concentrate with tibn. Water was advertised ad-libitum. The work was performed in understanding with the rules set by the Moral Committee of Menoufia University, Egypt.

\section{Experimental design:}

\section{Experiment 1.}

Each calf was injected intravenously into the cleared out jugular vein with a single dose of $2.2 \mathrm{mg} / \mathrm{kg}$.b.wt. of ceftiofur sodium (Altan et al., 2017). These calves were cleared out for fifteen days after the intravenous infusion to guaranteed total excretion of ceftiofur from their bodies.

\section{Experiment 2.}

It incorporates the same clearly solid pre-weaned calves of the primary test after fifteen days. Each calf was infused subcutaneously with ceftiofur sodium at a single dosage of $2.2 \mathrm{mg} / \mathrm{kg} . \mathrm{b} . \mathrm{wt}$. (Fernández-Varón et al., 2016).

\section{Blood samples.}

Blood samples $2 \mathrm{ml}$ were collected from the left jugular vein of each calf. After intravenous injection, samples were collected at $(0.083,0.25,0.5,1,2,4,8,12$, 18 and $24 \mathrm{~h}$ post administration. After subcutaneous injection, samples were collected at $(0.25,0.5,1,2,4,8,12,18,24$ and $36 \mathrm{~h}$ post administration. All blood samples were centrifuged at $3000 \mathrm{rpm}$ for 10 minutes, and serum was harvested and stored frozen at $-20{ }^{\circ} \mathrm{C}$ until analyzed for ceftiofur sodium.

\section{Preparation of standard curves of ceftiofur in serum:}

A standard solution $1000 \mu \mathrm{g} / \mathrm{ml}$ of Ceftiofur in deionized $\mathrm{H} 2 \mathrm{O}$ was arranged. All standard solutions were kept at $+4^{0} \mathrm{C}$. Functioning solutions of Ceftiofur used to confound plasma were arranged at 10.00 , 1.00 and $0.10 \mu \mathrm{g} / \mathrm{ml}$ concentrations from standard solutions by attenuating with deionized water. Standard concentrations were gotten by extra attenuation in drug free normal calves serum to attain concentrations $0.05,0.10,0.25,0.50$, $1.00,5.00,10.0$ and $25.0 \mu \mathrm{g} / \mathrm{ml}$ for creation of standard curve of ceftiofur according to (Altan et al., 2017) as illusterated in fig (1). 


\section{Analytical analysis}

Serum concentrations of ceftiofur were decided employing a high performance liquid chromatographic (HPLC) method. Drug free normal calves serum was pointed with ceftiofur from the once arranged concentration. Ceftiofur was taking out according to (Altan et al., 2017). In an eppindorf tube, In passing, nearly $200 \mu \mathrm{l}$ of each serum sample was taken and $200 \mu$ of methanol was added then samples were vortexed for $30 \mathrm{sec}$. Later centrifugation at $13,000 \mathrm{~g}$ for $10 \mathrm{~min}$ at $22^{\circ} \mathrm{C}$, clear supernatant was reassigned to $2 \mathrm{ml}$ micro centrifuge tubes, $100 \mu \mathrm{l}$ of $10 \%$ dithioerythritol in borate buffer was extra to each tube, and each tube was sited in a $\mathrm{H} 2 \mathrm{O}$ bath at $50^{\circ} \mathrm{C}$ for $15 \mathrm{~min}$. Tubes were moved from the $\mathrm{H} 2 \mathrm{O}$ bath and permitted to reach room temperature then $100 \mu \mathrm{l}$ of $23.3 \%$ iodoacetamide in phosphate buffer was added to each tube, tubes were covered in aluminum foil and shaken at $350 \mathrm{rpm}$ for $45 \mathrm{~min}$ at room temperature. $25 \mu \mathrm{l}$ of formic acid was extra to each tube. Following derivatization, samples were vortexed for $30 \mathrm{sec}$ after stirring at $22^{\circ} \mathrm{C}$, and were centrifuged for $10 \mathrm{~min}$ at 13,000 rpm. An aliquot of 20 ulof supernatant was filtrated with $0.45 \mu \mathrm{m}$ and transferred into the auto-sampler vial for analysis.

\section{Pharmacokinetic analysis:}

Serum concentrations of ceftiofur versus time curve were created, and best fitted by the help of computer polyexponential bend stripping program, ( $R$ Strip Micromath, software, USA). Data from each goat was fitted individually, and the pharmacokinetic variables were computed by the aid of the software programs. The hybrid rate constants of the distribution and elimination phase $(\alpha$ and $\beta$ ), and the first order absorption and elimination rate constants $(\mathrm{K}$ ab and $\mathrm{Kel}_{\mathrm{el}}$ and corresponding extrapolated zero time intercepts (A and B), absorption, distribution and elimination half-lives (t $0.5 \mathrm{ab}, \mathrm{t} 0.5 \mathrm{\alpha}, \mathrm{t} 0.5 \beta, \mathrm{t} 0.5 \mathrm{el}$ ), transfer rate constants $\left(\mathrm{K}_{12}\right.$ and $\left.\mathrm{K}_{21}\right)$. The area under the curve from zero to infinite time $\left(\mathrm{AUC}_{0-\infty}\right)$, mean residence time (MRT), maximum serum concentration $\left(\mathrm{C}_{\max }\right)$ and time to be achieved $\left(\mathrm{T}_{\max }\right)$ were calculated. The other pharmacokinetic parameters as total body clearance, the volume of the central compartment $\left(\mathrm{V}_{\mathrm{c}}\right)$, the volume of distribution at steady state ( $\left.V_{d s s}\right)$ (Baggot, 1978). The results were expressed as mean $\pm S E$ and the obtained data statistically using Student "t" test as described by (Snedecor, 1969).

\section{RESULTS}

\section{After a single intravenous injection of ceftiofur}

Serum concentrations of ceftiofur sodium after a single intravenous injection at dosage of $2.2 \mathrm{mg} / \mathrm{kg}$ b.wt. Ceftiofur were (16.72 \pm $0.197 \mu \mathrm{g} / \mathrm{ml})$ at $0.083 \mathrm{~h}$ and $(1.59 \pm 0.11$ $\mu \mathrm{g} / \mathrm{ml})$ at $24 \mathrm{~h}$ after organization as arranged in table (1) and portrayed in figure (2).

Deposition kinetic of ceftiofur mentioned in table (2). the distribution half - life [to.5( $\alpha$ ] equivalent to $0.11 \pm 0.01 \mathrm{~h}$. The volume of distribution of ceftiofur into the central compartment [ $\mathbf{V}^{1} \mathrm{c}$ ] was $0.12 \pm 0.002 \mathrm{~L} / \mathrm{kg}$. where the total body distribution measured by extrapolation area [ $\left.\mathbf{V}_{\mathrm{d}(\text { area })}\right]$ and steady -state [ $\mathrm{V}_{\mathrm{dss}}$ ] methods were $0.2 \pm 0.003$ and $0.16 \pm$ $0.004 \mathrm{~L} / \mathrm{kg}$ in that order. Ceftiofur was transmitted from central to peripheral compartment [K $\mathbf{K}_{12}$ ] equal to $1.70 \pm 0.13 \mathrm{~h}^{-1}$ while its passageway beginning the peripheral towards the central compartment [K21] equal to $4.80 \pm 0.40 \mathrm{~h}^{-1}$ ceftiofur was eliminated after intravenous injection with half

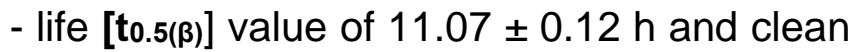
by all clearance processes in the body [ $\mathbf{C l}_{\text {tot }}$ ] at a rate of $0.013 \pm 0.005 \mathrm{~L} / \mathrm{kg} / \mathrm{h}$.

\section{After a single subcutaneous injection of ceftiofur}

The cruel serum concentrations of ceftiofur at distinctive time interims taking after a 
single subcutaneous dosage of ceftiofur in pre-weaned calves $(2.2 \mathrm{mg} / \mathrm{kg})$ was in corporate in table (1) and depicted in figure (2). Ceftiofur was firstly recognized $(0.78 \pm 0.03 \mu \mathrm{g} / \mathrm{ml})$ at 15 minutes post infusion and the most extreme serum level $(6.56 \pm 0.085 \mu \mathrm{g} / \mathrm{ml})$ accomplished 4 hours post infusion and still inside perceptible restrain for $36 \mathrm{hr}$.

The pharmacokinetic values for ceftiofur after its subcutaneous injection was tabulated in table (2). The crest concentration $\left(\mathrm{C}_{\max } 6.64 \pm 0.08 \mu \mathrm{g} / \mathrm{ml}\right)$ was come to $\left(T_{\max } 3.38 \pm 0.069 \mathrm{~h}\right)$. The drug was absorption half-life [t0.5(ab)] of $(0.74 \pm$ $0.03 \mathrm{~h}$ ) and eliminated with half-life time[to.5el)] was( $2.11 \pm 0.25 \mathrm{~h})$.

The area under curve (AUC) was (119.92 $\pm 1.08 \mu \mathrm{g} / \mathrm{ml}$.h). The systemic bioavailability (F\%) of ceftiofur following its subcutaneous injection of $2.2 \mathrm{mg} / \mathrm{kg}$ in preweaned calves was loud to be $(77.04 \pm 1.64 \%) \quad$ indicating moderate absorption of ceftiofur following subcutaneous injection.

\section{DISCUSSION}

Since 1991, Ceftiofur has been affirmed and widely utilized by veterinarians in the treatment of bacterial contaminations in cattle, swine, and horses. In the current test, ceftiofur deposition kinetics were determined in pre-weaned calves after a single i.v. furthermore s.c. administration at dose of $2.2 \mathrm{mg} / \mathrm{kg}$ b.wt.

After intravenous administration, ceftiofur was recognized in calves serum up to $24 \mathrm{~h}$ after ceftiofur sodium at dose of $2.2 \mathrm{mg} / \mathrm{kg}$. b.wt. Pharmacokinetic research of an antibiotic is a prerequisite for clinical recommendation (wang et al., 2018). Our outcomes indicated that ceftiofur was quickly and generally appropriated after IV administration with a distribution half-life (to.5a) of $0.11 \pm 0.01 \mathrm{~h}$ and $\mathrm{V}_{\text {dss }}$ of $0.16 \pm 0.004 \mathrm{~L} / \mathrm{kg}$, suggesting a good tissue penetration. This result of distribution volume at steady state ( $\left.\mathbf{V}_{\text {dss }}\right)$ almost consistent with the results of ceftiofur administration intravenously in lactating goats $(0.18 \mathrm{~L} / \mathrm{kg}$, Tohamy, 2008 and Fernández-Varón et al.,2016 ) ,camels (0.13 L/kg Goudah, 2007), calves $\left(0.25 \mathrm{~L} / \mathrm{kg}\right.$, Brown et al.,1996) and $V_{d s s}$ was lower than that expressed after intravenous administration of ceftiofur in a 7-day, 1month and 9 months age calves (0.34, 0.33, $0.300 \mathrm{~L} / \mathrm{kg}$, Brown et al.,1996) respectively, buffalo calves $(0.53$ $\mathrm{L} / \mathrm{kg}$, Sudamrao, 2015) and cows (0.30 L/kg, Liu et al., 2010).

The estimation of distribution half-life (to.5a) in this test was in concurrence with values recorded in buffalo calves to.5a (0.19 \pm 0.008 h. (Sudamrao, 2015) , cefepime in goats $(0.20 \pm 0.004$ ElHewaity, 2014), cefepime in sheep (0.2 \pm $0.02 \mathrm{~h}$, Patel et al.,2010), cefepime in calves $(0.25 \pm 0.07 \mathrm{~h}$, Pawar and Sharma 2008), cefepime in ewes $(0.18 \pm 0.008 \mathrm{~h}$, Ismail, 2005) and cefepime in buffalo calves $(0.18 \pm 0.05 \mathrm{~h}$, Joshi and Sharma 2007). While longer half-life of distribution of ceftiofur was recorded of ceftiofur in rabbits (0.34 $\pm 0.07 \mathrm{~h}$; Kamil et al., 2015), cattle $(0.462 \mathrm{~h}$; Tohamy, 2008), camel (0.48 \pm 0.07 ; Goudah, 2007), bull calves 6 and 9 months $(0.88,0.74 \mathrm{~h}$; Brown et al., 1996), lactating and nonlactating goats (0.69h, 0.8h;Courtin et al., 1997), sheep (4.8h; Craigmill et al.,1997).

After intravenous injection of ceftiofur in pre-weaned calves, the outcomes indicated elimination half-life $\left(\mathbf{t}_{0.5(\beta)}\right)(11.07$ \pm 0.12 hours) that nearly reliable with buffalo calves (12.6h, Sudamrao, 2015) and this worth was higher than that announced in 3 months old calves $(8.22 \mathrm{~h}$, Brown et al.,1996) and in dairy cows (7.45 $\pm 0.70 \mathrm{~h}$, wang et al., 2018) and lower than that referenced in cows (15.3h, Liu et al., 2010) and 7-day and 1month old calves(16.10 and 17.16h,Brown et al.,1996). 
Total body clearance of ceftiofur ( $\left.\mathbf{C l}_{\text {tot }}\right)$ was $(0.013 \pm 0.005 \mathrm{~L} / \mathrm{kg} / \mathrm{h})$. this mean more slow ceftiofur disposal after intravenous administration of $2.2 \mathrm{mg} / \mathrm{kg}$ b.w. This $\left(\mathbf{C l}_{\text {tot }}\right)$ value was almost comparable to those reported in 7-day and 1month old calves (0.017,0.016L/kg/h, Brown et al.,1996), goats $(0.013 \mathrm{~L} / \mathrm{kg} / \mathrm{h}$, Liu et al.,2010).

Ceftiofur accomplished a greatest focus $\left(\mathrm{C}_{\max }\right)$ of $6.64 \pm 0.08 \mu \mathrm{g} / \mathrm{ml}$ at $\left(\mathrm{t}_{\max }\right)$ of $3.38 \pm 0.069 \mathrm{~h}$ which is about marginally like that detailed in lactating goats $(6.52 \mu \mathrm{g} / \mathrm{ml}$, Fernández-Varón et al., 2016), calves (8.56, 5.62 and 7.66 $\mu \mathrm{g} / \mathrm{ml}$, Hornish and Kotarski 2002, Woodrow et al., 2016 and Foster et al., 2016 ) respectively, and higher than that announced in dairy cows (0.88 \pm $0.21 \mu \mathrm{g} / \mathrm{ml}$, wang et al., 2018) and in buffalo calves $(2.99 \mu \mathrm{g} / \mathrm{ml}$, Sudamrao, 2015) and lower than that revealed in cats $(14.99 \pm 2.29 \mu \mathrm{g} / \mathrm{ml}$, Zhang et al., 2019) which received ceftiofur sodium at dose $5 \mathrm{mg} / \mathrm{kg}$.b.wt.

In our investigation, the mean residence time (MRT) following subcutaneous administration is (12.93 \pm 0.13$)$ hours and this concur with lactating dairy cattle (11 h, Wang et al.,2018) and disagree with calves (26.2h, Woodrow et al., 2016) and lactating goats (6.29h, Fernández-Varón et al., 2016).

The importance of area under the curve (AUC) after subcutaneous administration of ceftiofur in this examination is (119.92 $\pm 0.08 \mu \mathrm{g} / \mathrm{ml} . \mathrm{h})$ and this result nearly consistence with those of calves (93.6 and 137.63 $\mu \mathrm{g} / \mathrm{ml} . \mathrm{h}$, Woodrow et al.,2016 and Foster et al.,2016 ) respectively, cattle (105 and $95.8 \mu \mathrm{g} / \mathrm{ml} . \mathrm{h}$, Brown et al., 2000 and Hornish and Kotarski 2002) respectively. Be that as it may, this outcomes not in consistence with those detailed in 9 months old calves and buffalo calves $(77.3$ and $36.2 \mu \mathrm{g} / \mathrm{ml} . \mathrm{h}$, Brown et al.,1996 and Sudamrao, 2015) respectively, lactating goats $(38.17 \mu \mathrm{g} / \mathrm{ml} . \mathrm{h}$, Fernández-Varón et al.,2016) and lactating dairy cows (36.52, $10.96 \mu \mathrm{g} / \mathrm{ml} . \mathrm{h}$, Okker et al.,2002 and Wang et al.,2018) respectively.

Bioavailability of ceftiofur after s.c. injection was $77.04 \pm 1.64 \%$ and this concur with that of buffalo calves (72\%; Sudamrao, 2015), lactating dairy cows (62\%; Wang et al., 2018), lactating goats (85\%; Fernández-Varón et al., 2016), and cats (82.95\%, Zhang et al., 2019).

Riond et al., 1989 guessed that the contrasts between determined parameters for pharmacokinetic studies may be referred to drug formulations, the sex, size or age of the animals, discrepancies in deposits of fatty tissue between breeds or species of animals, and even interindividual variations.

\section{Conclusion}

The main cause of disease in preweaned calves as diarrhea and respiratory infections is bacterial cause so, Antibiotics treatment is a significant instrument in decreasing both the frequency and mortality related with these sicknesses. It could be inferred that S/C administration of ceftiofur at dose of 2.2 $\mathrm{mg} / \mathrm{kg}$.b.wt. accomplished great serum focuses covering the sensitive bacteria to it, which may be highly efficacious against susceptible bacteria in pre-weaned calves.

\section{Conflict of Interests}

The author declares that there is no conflict of interests regarding the publication of this article 
Table 1. Mean serum concentration $(\mu \mathrm{g} / \mathrm{ml})$ of ceftiofur in pre-weaned calves after a single I.V. and S/C. administration of $2.2 \mathrm{mg} / \mathrm{kg}$ b.wt. $(n=5)$.

\begin{tabular}{|c|c|c|}
\hline \multirow{2}{*}{ Time } & \multicolumn{2}{|c|}{ Groups ( X \pm S.E. $)$} \\
\cline { 2 - 3 } & Cef. $I . V$. & Cef. S/C. \\
\hline 0.083 & $16.72 \pm 0.197$ & $-\cdots--$ \\
\hline 0.25 & $14.84 \pm 0.14$ & $0.78 \pm 0.03$ \\
\hline 0.5 & $13.66 \pm 0.15$ & $1.92 \pm 0.05$ \\
\hline 1 & $12.86 \pm 0.10$ & $4.61 \pm 0.11$ \\
\hline 2 & $12.01 \pm 0.067$ & $5.88 \pm 0.088$ \\
\hline 4 & $11.30 \pm 0.98$ & $6.56 \pm 0.085$ \\
\hline 8 & $8.69 \pm 0.13$ & $5.44 \pm 0.11$ \\
\hline 12 & $6.72 \pm 0.11$ & $4.45 \pm 0.119$ \\
\hline 18 & $5.49 \pm 0.12$ & $3.51 \pm 0.12$ \\
\hline 24 & $1.59 \pm 0.11$ & $2.13 \pm 0.062$ \\
\hline 36 & $-\cdots----$ & $0.98 \pm 0.06$ \\
\hline
\end{tabular}


Fig. 1. Semilogarithmic graph showing standard curve of ceftiofur in calve's serum.

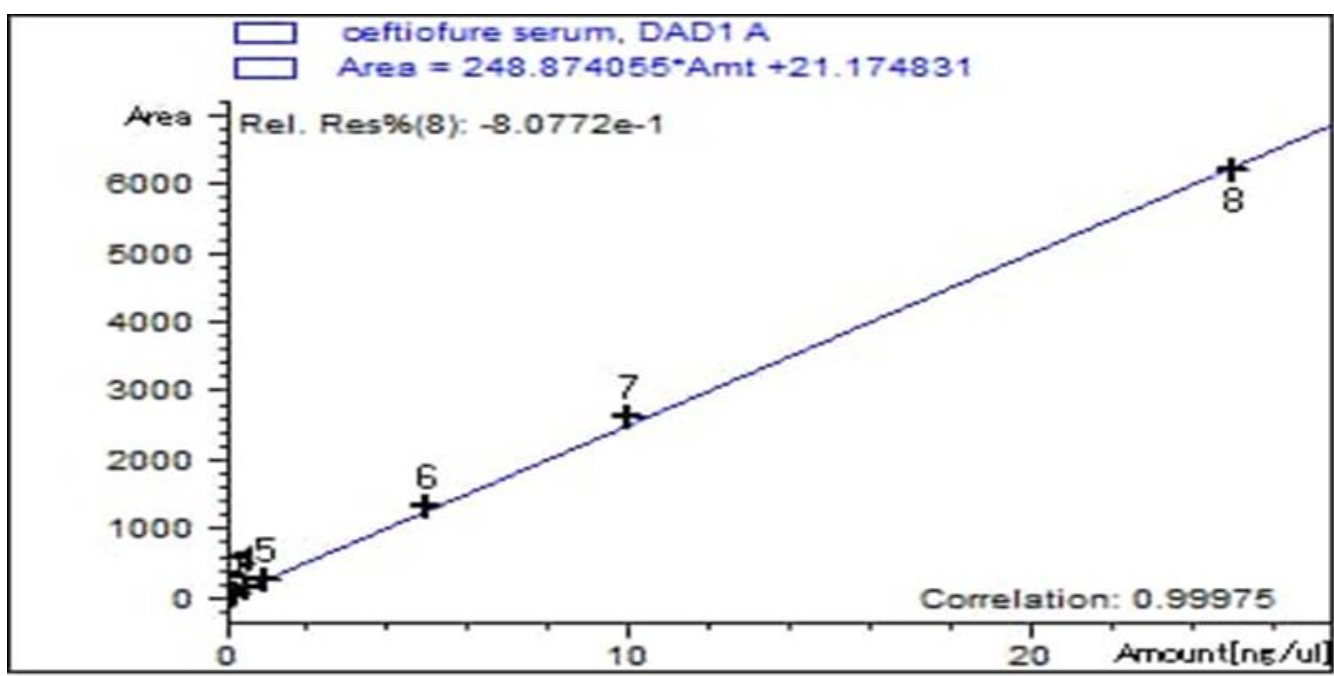


Table 2. Mean pharmacokinetic parameters of ceftiofur in pre-weaned calves after a single I.V. and $S / C$ administration of $2.2 \mathrm{mg} / \mathrm{kg}$ b.wt. $(n=5)$.

\begin{tabular}{|c|c|c|c|}
\hline Parameter & Unit & $\overline{\mid I V}$ & SC \\
\hline$\alpha\left(K_{a b}\right)$ & $h^{-1}$ & $6.86 \pm 0.45$ & $0.90 \pm 0.04$ \\
\hline$T_{0.5 a}\left(T_{0.5 \mathrm{ab}}\right)$ & $\mathrm{h}$ & $0.11 \pm 0.01$ & $0.74 \pm 0.03$ \\
\hline$\beta\left(K_{\mathrm{el}}\right)$ & $h^{-1}$ & $0.062 \pm 0.006$ & $0.057 \pm 0.001$ \\
\hline $\mathrm{T}_{0.5 \beta}\left(\mathrm{T}_{0.5 \mathrm{el}}\right)$ & $h$ & $11.07 \pm 0.12$ & $12.11 \pm 0.25$ \\
\hline $\mathrm{V}_{\mathrm{c}}$ & $\mathrm{L} \mathrm{kg}^{-1}$ & $0.12 \pm 0.002$ & --- \\
\hline$V_{\text {dss }}$ & $\mathrm{L} \mathrm{kg}^{-1}$ & $0.16 \pm 0.004$ & --- \\
\hline $\mathrm{V}_{\mathrm{d}(\text { area })}$ & $\mathrm{L} \mathrm{kg}^{-1}$ & $0.20 \pm 0.003$ & --- \\
\hline $\mathrm{K}_{12}$ & $h^{-1}$ & $1.70 \pm 0.13$ & 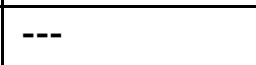 \\
\hline $\mathrm{K}_{21}$ & $h^{-1}$ & $4.80 \pm 0.40$ & --- \\
\hline $\mathrm{Cl}_{\text {tot }}$ & $\mathrm{L} \mathrm{kg}^{-1} \mathrm{~h}^{-1}$ & $0.013 \pm 0.005$ & --- \\
\hline $\mathrm{C}_{\max }$ & $\mu \mathrm{g} \cdot \mathrm{ml}^{-1}$ & --- & $6.64 \pm 0.082$ \\
\hline$T_{\max }$ & $h$ & --- & $3.38 \pm 0.069$ \\
\hline AUC & $\mu \mathrm{g} \cdot \mathrm{h} \cdot \mathrm{ml}^{-1}$ & $155.73 \pm 4.23$ & $119.92 \pm 1.08$ \\
\hline MRT & $\mathrm{h}$ & $9.058 \pm 0.03$ & $12.93 \pm 0.13$ \\
\hline $\mathrm{F}$ & $\%$ & & $77.04 \pm 1.46$ \\
\hline
\end{tabular}

$\mathrm{K}_{\mathrm{ab}}$ : First-order absorption rate constant; $\mathrm{T}_{0.5(\mathrm{ab})}$ : Absorption half-life; $\mathrm{K}_{\mathrm{el}}$ : First-order elimination rate constant; $\mathrm{T}_{0.5(\mathrm{ell})}$ : Elimination half-life; $\mathrm{C}_{\max }$ : Maximum serum concentration; $\mathrm{T}_{\max }$ : Time to peak serum concentration; $\mathrm{AUC}_{(0 \text {-inf) }}$ : Area under serum concentration-time curve; MRT: Mean residence time; $F$ fraction of drug absorbed systemically after IM injection. $T^{1} 1 / 2(\alpha)$ : Distribution half-life; Vc: Apparent volume of central compartment; $\mathrm{Vd}($ area): Apparent volume of distribution calculated by area method ; Vdss: Volume of distribution at steady state; K12 : First-order constant for transfer from central to peripheral compartment; K21: First-order constant for transfer from peripheral to central compartment; Kel: Elimination rate constant; $\mathrm{T}^{1} / 2(\beta)$ : Elimination half-life; $\mathrm{AUC}(0$-inf): Area under serum concentration-time curve; MRT: Mean residence time; Cltot: Total body clearance. 
Fig. 2. Graph depicting the time course of ceftiofur in serum of pre-weaned calves after a single I.V. and S.C. administration of $2.2 \mathrm{mg} / \mathrm{kg} \mathrm{b.wt.}(\mathrm{n}=5)$.

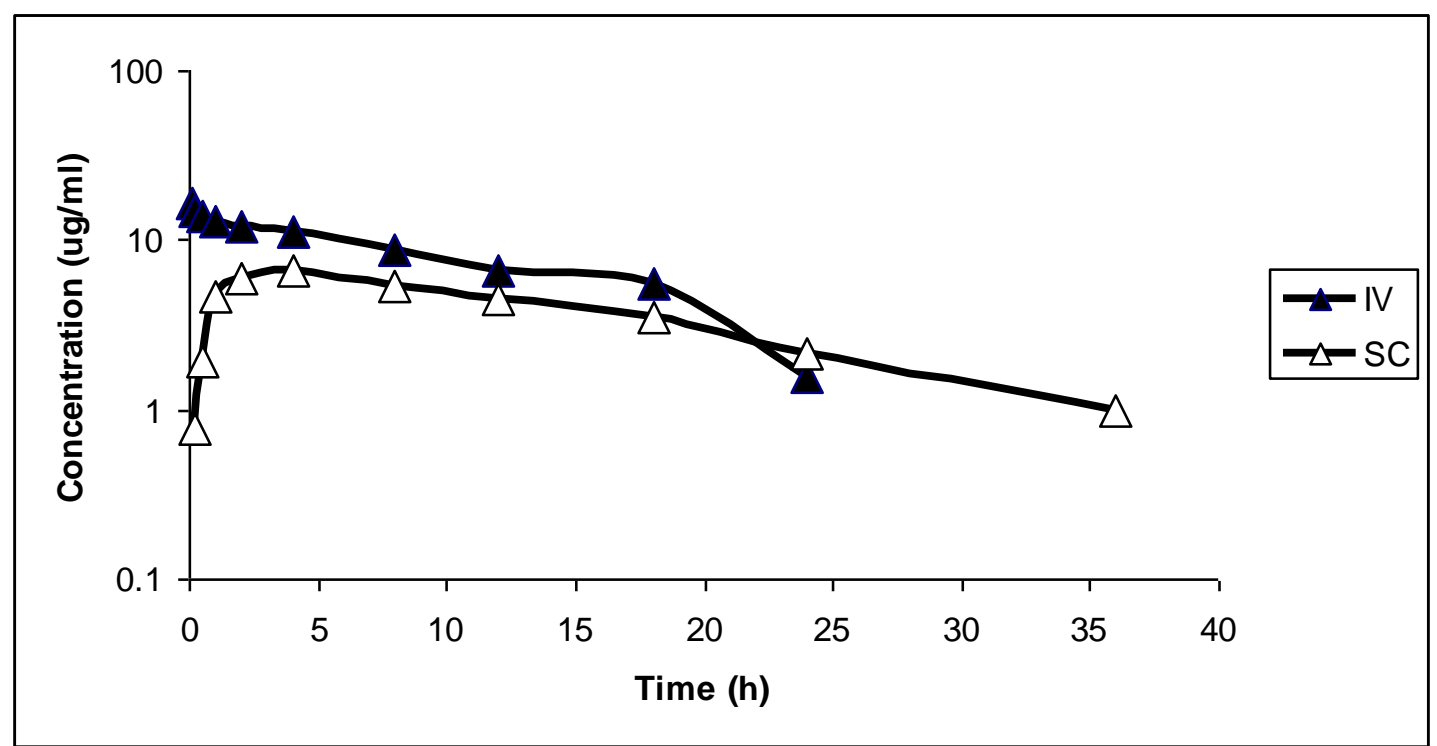




\section{REFERENCES}

Altan, F., Uney, K., Er, A., Cetin, G., Dik, B., Yazar, E., \&Elmas, M. (2017). Pharmacokinetics of ceftiofur in healthy and lipopolysaccharide-induced endotoxemic newborn calves treated with single and combined therapy. Journal of Veterinary Medical Science, 16-0641.

Baere S De, Pille F, Croubels S, Ceelen $L$ and Backer $P$ De. (2004). Highperformance liquid chromatographic-UV detection analysis of ceftiofur and its active metabolite desfuroylceftiofur in horse plasma and synovial fluid after regional intravenous perfusion and systemic intravenous injection of ceftiofur sodium.Analytica Chimica Acta 512: 7584.

Baggot, J.D.(1978). Some aspects of clinical pharmacokinetics in veterinary medicine. J. Vet. Pharmacol. Ther., 1: 518.

Brown, S. A., Chester, S. T. and Robb, E. J. (1996). Effects of age on the pharmacokinetics of single dose ceftiofur sodium administered intramuscularly or intravenously to cattle. J. Vet. Pharmacol. Ther. 19: 32-38.

Courtin, F., Craigmill, A. L., Wetzlich, S. E., Gustafson, C. R., \& Arndt, T. S. (1997).Pharmacokinetics of ceftiofur and metabolites after single intravenous and intramuscular administration and multiple intramuscular administrations of ceftiofur sodium to dairy goats. Journal of veterinary pharmacology and therapeutics, 20(5), 368-373.

Craigmill, A. L., Brown, S. A., Wetzlich, S. E., Gustafson, C. R., \& Arndt, T. S. (1997). Pharmacokinetics of ceftiofur and metabolites after single intravenous and intramuscular administration and multiple intramuscular administrations of ceftiofur sodium to sheep. Journal of veterinary pharmacology and therapeutics, 20(2), 139-144.
El-Hewaity, M. (2014). Influence of flunixin on the disposition kinetic of cefepime in goats. Advances in Pharmacological Sciences, Volume 2014

Fernández-Varón, E.; Cárceles-García, C.; Serrano-Rodríguez, J.M. and CárcelesRodríguez, C.M. (2016). Pharmacokinetics (PK), pharmacodynamics (PD), and PK-PD integration of ceftiofur after a single intravenous, subcutaneous and subcutaneous-LA administration in lactating goats. BMC Veterinary Research , 12:232.

Foster, D. M., Jacob, M. E., Warren, C. D., \&Papich, M. G. (2016). Pharmacokinetics of enrofloxacin and ceftiofur in plasma, interstitial fluid, and gastrointestinal tract of calves after subcutaneous injection, and bactericidal impacts on representative enteric bacteria.Journal of veterinary pharmacology and therapeutics, 39(1), 62-71.

Goudah, A. (2007). Pharmacokinetics of ceftiofur after single intravenous and intramuscular administration in camels (Camelusdromedarius). Journal of veterinary pharmacology and therapeutics, 30(4), 371374.

Hornish, R. E., \& Katarski, S. F. (2002). Cephalosporins in veterinary medicineceftiofur use in food animals. Current topics in medicinal chemistry, 2(7), 717-731.

Ismail, M.M. (2005). Pharmacokinetics of Cefepime administered by I.V. and I.M. routes to ewes. J. Vet. Pharmacol.Ther.; 28: 499-503.

Joshi, B. and Sharma, S.K. (2007). Pharmacokinetic Disposition and Bioavailability of cefepime in buffalo calves. J. Vet. Pharmacol.Ther.; 30: 500-502.

Kamil U., Feray A., Ayse E., Enver Y. and Muammer E. (2015). Pharmacokinetics of ceftiofur after single intravenous and intramuscular injections in rabbits. J. Infect. Dis. Ther, 3:4, 2332-0877.S1.003

Kapoor,G.; Saigal, S. and Elongavan, A. (2017). Action and resistance mechanisms of antibiotics: A guide for clinicians. Journal 
of Anaesthesiology

Pharmacology. 33(3): 300-305.

Kausche, F. M. and Robb, E. J. (2003). A Comprehensive Review of Ceftiofur Sodium and Hydrochloride Formulations for Treatment of Acute Bovine Foot Rot Veterinary Therapeutics. 4 (1):83-93.

Liu S, Guo D, Guo $Y$ and Zhou W. (2010). Preparation and pharmacokinetics of ceftiofur sodium liposomes in cows. Journal of Veterinary Pharmacology and Therapeutics 34: 35-41.

Moore, D. (2019). Antibiotic Classification \&Mechanism.:https://www.orthobullets.co $\mathrm{m} /$ basic-science/9059/antibiotic classification-and-mechanism.

Okker, H., Schmitt, E. J., Vos, P. L. A. M., Scherpenisse, P., Bergwerff, A. A., \&Jonker, F. H. (2002). Pharmacokinetics of ceftiofur in plasma and uterine secretions and tissues after subcutaneous postpartum administration in lactating dairy cows. Journal of veterinary pharmacology and therapeutics, 25(1), 3338.

Patel, P.N., Patel, U.D., Bhavsar, Sh.K. andThaker, A.M. (2010). Pharmacokinetics of cefepime following intravenous and intramuscular administration in sheep. Iranian Journal of Pharmacology \& Therapeutics .17352657/10/91-7-10.

Pawar, Y.G. and Sharma, S.K. (2008). Influence of E.coli lipopolysaccharide induced fever on the plasma kinetics of cefepime in cross-bred calves. Vet. Res. Commun. 32:123-130.

Riond, J.L.; Tyczkowska, K. and Riviere, J.E. (1989). Pharmacokinetics and metabolic inertness of doxycycline in calves with mature or immature rumen function. Amer. J. Vet. Res. 50 (8): 13291333.

Salmon, S. A., Watts, J. L., Case, C. A., Hoffman, L. J., Wegener, H. C. and Yancey, R. J. (1995). Comparison of
MICs of ceftiofur and other antimicrobial agents against bacterial pathogens of swine from the United States, Canada, and Denmark. Journal of Clinical Microbiology 33(9): 2435-44.

Snedecor, G.W. (1969). Statistical methods. 4th ed. Ames, IA: The Lowa state University Press, 1969; 91.

Scott, H. M., Schouten, M. J., Gaiser, J. C., Belschner, A. P. and Jordan, E. R. (2005). Effect of intrauterine administration of ceftiofur on fertility and risk of culling in postparturient cows with retained fetal membranes, twins, or both. Journal of American Veterinary Medical Association 226: 2044-2052.

Stanek, C. and Kofler, J. (1998). Use of sodium ceftiofur in the combined therapy of complicated septic diseases in cattle.TierarztIPrax.Ausgabe G Grosstiere/ Nutztiere 26: 314-17.

Sudamrao, D. P. (2015). Pharmacokinetic and pharmacodynamic studies of ceftiofur in buffalo calves (doctoral dissertation, guru angaddev veterinary and animal sciences university).

Tohamy M A.( 2008). Pharmacokinetics of ceftiofur sodium administered concomitantly with dipyrone in healthy and feverish cows. Journal of Egyptian Society of Pharmacology and Experimental Therapeutics 29(2): 53951.

Wang, J., Peng, H., Kong, J., Zhao, T., Zhang, S., \& Cao, X. (2018). Pharmacokinetic profile of Ceftiofur Hydrochloride Injection in lactating Holstein dairy cows.Journal of veterinary pharmacology and therapeutics, 41(2), 301306.

Werth, P.J. (2018). Cephalosporins, Merck Manual for the Professional.

Witte, T. S., Iwersen, M., Kaufmann, T., Scherpenisse, P., Bergwerff, A. A. and Heuwieser, W. (2011). Determination of ceftiofur derivatives in serum, endometrial tissue, and lochia in puerperal dairy cows after subcutaneous administration of ceftiofur 
crystalline free acid. Journal of Dairy Science 94: 284-290.

Woodrow, J. S., Caldwell, M., Cox, S., Hines, M., \&Credille, B. C. (2016). Comparative plasma pharmacokinetics of ceftiofur sodium and ceftiofur crystallinefree acid in neonatal calves. Journal of veterinary pharmacology and therapeutics, 39(3), 271-276.

Zhang, M; Yang, F.; Yu, H.; Kang, T. ; Ding, Y.; Yu, M.; Wang, Q.; Zhu, Y. and Yang, F. (2019). Pharmacokinetics of ceftiofur sodium in cats following a single intravenous and subcutaneous injection. $J$ vet Pharmacol Therap:1-7. 
الملخص العربي

المسار الحركي للسيفتيفور صوديوم بعد الحقن الوريدي وتحت الجلد في العجول في مرحلة ما قبل الفطام محمد حمدي الحويطي

قسم الادوية- كلية الطب البيطري- جامعة النوفية

استهدفت هذه الدر اسة تقييم المسار الحركي و الاتاحة الحيوية للسيفتيفور صوديوم (2.2 مجم / كجم) بعد الحقن الوريدي وتحت الجلد في العجول في مرحلة ما قبل الفطام. تم تحديد تركيزات السيفتيفور في مصل الدم بواسطة تقنية الفحص باستخدام (HPLC) وأوضحت النتائج بعد الحقن الوريدي استمر ار تواجد السيفتيفور في المصل لمدة 24 ساعة بعد الحقن وكان التركيز 1.59 ميكروجرام لكل ملي. واظهرت النتائج بعد الحقن تحت الجلد تسجيل اعلي تركيز للسيفتيفور في المصل عند 3.38 ساعة ومعدل النصف للاخر اج كان 12.11 ساعة. وأثنارت النتائج الي ان معدل الاتاحة الحيوية 77.04 \% بعد الحقن تحت الجلد0 اعتمادا على المعطيات الناتجة عن هذه الدراسة وجد انه عند اعطاء السيفتيفور بجرعة 2.2 مجم / كجم فى الوريد او تحت الجلد انه سريع الامتصاص مع زيادة فى تركيزات الدواء تعلوا عن المستوى المطلوب (MIC) لقتل البكتريا الحساسة للسيفتيفور على مدار 24 و 36 ساعة بعد الحقن الوريدي وتحت الجلد في العجول في مرحلة ما قبل الفطام. 